\title{
No Jardim dos Suplícios: memórias da Guerra Colonial Portuguesa
}

\author{
Pedro Miguel Jorge Réquio* \\ ORCID iD 0000-0002-5450-5755 \\ Universidade de Coimbra, Centro de Estudos Sociais/Faculdade de Letras, Coimbra, Portugal
}

Resumo: Este ensaio tem por base uma série de entrevistas realizadas a indivíduos que participaram na Guerra Colonial Portuguesa e procura perceber o modo como a experiência de guerra contribuiu para a formação da identidade individual e coletiva, bem como para a percepção da alteridade e a sedimentação de preconceitos provenientes do ideal colonial. Estes depoimentos foram contextualizados no âmbito da história portuguesa, desde a época em questão até à atualidade.

Palavras-Chave: Guerra Colonial Portuguesa. Estudos da memória. África. Século XX. História Oral.

\section{The torture garden:}

\section{memories from the Portuguese Colonial War}

Abstract: This essay is based on a series of interviews with individuals who participated in the Portuguese Colonial War and seeks to understand how the war experience contributes to the formation of individual and collective identity, as well as to their perception of otherness and the sedimentation of prejudices arising from the colonial ideal. These testimonies were contextualized within the portuguese history, from the time in question until today.

Keywords: Portuguese Colonial War. Memory studies. Africa. XXth Century. Oral History.

Mestre em História Contemporânea pela Universidade de Coimbra (UC), com tese orientada pelo Dr. Rui Bebiano. Licenciado em História pela mesma instituição. E-mail: pedrorequio@hotmail.com. 


\section{Introdução}

Um dos propósitos deste trabalho é contribuir para salvaguardar a memória, coletiva e individual, ${ }^{1}$ acerca da Guerra Colonial Portuguesa (1961-1973). Nos últimos anos têm sido feitos esforços, académicos e civis, neste sentido. Atente-se, para além das investigaçóes cientificas, à quantidade de livros e filmes lançados que abordam temáticas convergentes. O propósito central é, no entanto, estudar o efeito que a guerra, e mais particularmente a Guerra Colonial, tem no sujeito individual e coletivo, procurando perceber a importância que essas experiências têm na formaçáo identitária e avaliar o grau de penetraçáo que o ideal colonial teve nos soldados. Ao mesmo tempo procurase contribuir para a preservação da memória das experiências de guerra dos soldados comuns, de forma a auxiliar a construçáo de um conhecimento sobre o tema que se alicerce nos depoimentos de homens vulgares, evitando assim narrativas mitificadas.

Para tal, foram levadas a cabo 8 entrevistas a indivíduos que, no âmbito do serviço militar obrigatório imposto pela ditadura Estado Novo, ${ }^{2}$ foram integrados em corpos militares destacados para a guerra. Os entrevistados cumpriram funçóes diversas e estiveram, no seu conjunto, nas três frentes (Guiné-Bissau, Angola e Moçambique). O propósito desta seleçáa prendeu-se com o facto de tentar demonstrar um amplo e diversificado conjunto de experiências que permitisse fazer uma leitura comparativa. Os depoimentos recolhidos para a elaboraçáo deste ensaio foram todos obtidos na mesma localidade, uma vila com cerca de 3.500 habitantes no centro de Portugal. Os nomes que constam na listagem são falsos, devido ao facto de alguns entrevistados não quererem a sua identidade revelada neste estudo.

Para auxiliar a contextualização e a interpretação dos depoimentos recolhidos será primeiro necessário proceder a uma breve exposição do ideário colonialista do Estado Novo, à mundivisão propalada pelo sistema educacional português da época e aos acontecimentos que pautaram os conflitos nos territórios coloniais portugueses.

A ideologia colonial do regime salazarista encarava todos os territórios ultramarinos não como partes subordinadas a uma metrópole central e capital do império, mas como elementos integrados numa "nação pluricontinental, una e indivisível" (Rosas, 1994, p. 485-486). Se a mística imperial explícita, corporizada através do Acto Colonial (1930), matizava a princípio a postura identitária do Portugal estado-novista, ela viria a ser alterada, em termos meramente formais, após o fim da Segunda Guerra mundial.

Ou seja, com a derrota do nazi-fascismo e com a consagraçâo dos princípios

1 Por memória individual entendem-se as memórias que o individuo guarda acerca de si próprio, por coletiva, as memórias que cada pessoa guarda acerca de um grupo que fez parte.

2 Ditadura de cunho nacionalista que vigorou em Portugal entre 1933 e 1974. 
autodeterministas dos povos colonizados na Declaração Universal dos Direitos do Homem (1948), a Organizaçáo das Naçóes Unidas (ONU) passou a forçar as potências coloniais a prepararem os territórios sobre a sua tutela para a obtençáo da independência. Em 1951, com a revisão da Constituição Política da República Portuguesa, Salazar apresenta uma proposta da revogaçáo do Acto Colonial que, ao invés de o abolir efetivamente, introduz-lhe alteraçóes terminológicas e outros pequenos ajustes. O estatuto legal dos colonizados é alterado, mas na prática as suas condiçôes de vida precárias persistem. O termo Império Colonial Português, que adquirira uma conotação pejorativa no quadro internacional, é abolido. Também a designação dos territórios africanos e asiáticos como "colónias" é substituída por "províncias ultramarinas". De acordo com essa nova conjuntura, Portugal apresenta-se com uma "nação pluricontinental", composta por províncias europeias e ultramarinas, harmoniosamente integradas num corpo nacional.

Consequentemente, nas campanhas de propaganda difundidas, nacional e internacionalmente, que reclamavam para si e deturpavam o conceito de lusotropicalismo, ${ }^{3}$ bem como através do sistema educacional dirigido às populaçóes continentais, Portugal apresentava-se enquanto "bom colonizador" e, de acordo com esta lógica, contribuía para a fraternidade entre os povos mundiais e para a integração de raças e culturas diferentes na mesma nação (Castelo, 2013).

O regime político do Estado Novo inculcava o seu sistema de valores na população portuguesa - "Deus", "Pátria", "Família" - através de diversos mecanismos de propaganda e organizaçóes: Secretariado de Propaganda Nacional (SPN), sindicatos nacionais, casas do povo, Mocidade Portuguesa e Federaçáo Nacional para a Alegria no Trabalho (FNAT). Estes aparelhos explícitos de enquadramento de valores vertiam os seus ideários para as próprias escolas do ensino básico que contribuíam, por sua vez, para os cimentar e consensualizar. $\mathrm{O}$ cidadáo comum, educado durante o período do Estado Novo, vivia assim imerso num "quotidiano que se aspirava a ver enquadrando, organizado e vivido no espírito do regime" (Rosas, 1994, p. 293).

À luz da historiografia e dos depoimentos recolhidos conclui-se que os soldados mobilizados para a guerra estariam imbuídos nos valores do nacionalismo salazarista, consequentemente encarando o guerrilheiro independentista enquanto terrorista que visava, mais do que autonomia, à derrocada da nação pluricontinental portuguesa.

3 O conceito de luso-tropicalismo, criado pelo sociólogo brasileiro Gilberto Freyre durante a década de 1930, postulava que os portugueses tiveram a capacidade para criar uma civilização mestiça transcontinental devido à sua origem peninsular hibrida - onde a cultura árabe, judia e cristã se interpenetraram. $\mathrm{O}$ Estado Novo só reconheceu esta teoria na década de 1950, chegando inclusive a convidar Freyre a visitar as colónias. Todavia, esvaziou o seu conteúdo de miscigenação cultural. Aproveitando somente o termo de uma civilização global luso-tropical para caracterizar a sua relação com as colónias como sendo intrinsecamente positiva (Castelo, 1999). 


\section{Estranhos numa terra estranha}

Deacordo com as declaraçôes recolhidas, os indivíduos revelaram que as expectativas da futura experiência de guerra se baseavam num profundo desconhecimento do que os esperava ou em ideias pré-concebidas que foram estilhaçadas após a chegada a África. Parte significativa dos entrevistados foi mobilizada nos últimos anos da guerra, o que certamente contribuiu para que tivessem uma visão diferente dos que foram enviados durante os primeiros anos do conflito. Importa sublinhar que as notícias sobre o confronto veiculadas pela imprensa portuguesa da época mitigavam consideravelmente a violência do mesmo e ocultavam certamente os eventos mais desastrosos.

Quanto às expectativas propriamente ditas, as opiniôes variam. Mário afirmou que "antes de se ir para lá náo se tinha ideia nenhuma" (Mário, 2019). Todavia, quando indagado se houve um grande desfasamento entre as expectativas e as ocorrências verificadas no local, respondeu afirmativamente. Já Carlos, amanuense e distribuidor de material, asseverou que "as expectativas não eram muito más" porque "não estava no mato. Quem ia para lá é que tinha de lidar com o tiroteio e as minas. Quem estava na cidade era como estar cá em Portugal. A guerra era só no mato" (Carlos, 2019). Gabriel, por exemplo, declarou que não tinha ideia nenhuma do que o esperava e que ao início até pensava que a guerra não existia. Foi só depois, ao cumprir as suas tarefas como transmissor de informaçáo via rádio e ao tomar conhecimento dos mortos e feridos, e que pode comprovar a veracidade do conflito" (Gabriel, 2019). Já Nuno, que esteve como atirador de cavalaria na Guiné-Bissau, na zona de Guileje, declarou:

Já sabíamos que íamos para o mato. Para a guerra. Era matar ou morrer. Houve muita porrada. Estive numa das zonas mais intensas, que era a poucos quilómetros da fronteira com Conakry, onde os 'turras' tinham as bases. $\mathrm{Ou}$ seja, íamos para lá com a ideia que aquilo ia ser duro. Só que ficou ainda pior do que esperávamos. Ainda por cima a partir de 1972, quando os gajos começaram a estar mais apetrechados. Até já derrubavam aviôes com mísseis. Foi tramado. (Nuno, 2019).

Alves, que esteve igualmente na Guiné-Bissau, em Buba, a norte de Guileje, afirmou que o soldado comum poderia ter uma ideia generalizada do perigo, mas nada de concreto. Sublinhou que grande parte das pessoas com quem conviveu era "extremamente humilde e não tinha a menor ideia do que os aguardava. Vinham do Minho, do Alentejo. Metade deles não tinha a quarta classe sequer" (Alves, 2019). Alves contou também que no próprio dia do desembarque o fatalismo se instaurou em si e nos seus colegas:

A perspetiva que tínhamos era de que podíamos não regressar. Tivemos um discurso do capitão Carlos Fabiáo que dizia que muitos de nós não iriamos regressar para 
as nossas mães, mulheres, namoradas, filhos ou familiares. O Spínola também estava lá, a dizer que a Guiné era como o Vietname. Não era como Angola ou Moçambique. Uma pessoa até fica com lágrimas nos olhos. Alias, no próprio dia desse discurso tivemos a primeira baixa. Por azar o meu, foi um colega que tinha acabado de conhecer [...]. (Alves, 2019).

O sentimento consensual entre os veteranos postula que nenhuma vivência, expectativa, treino militar ou pré-concepção pode preparar o indivíduo para a experiência do conflito militar. A acrescentar ao desconforto provocado pela situação militar juntase o sentimento de profundo desenraizamento despoletado pelo afastamento dos soldados das suas localidades e famílias e a sua inserção num continente onde tudo parece bizarro, hostil e desconcertante. O "Portugal uno e indivisível" de António de Oliveira Salazar, onde um luso-tropicalismo domesticado determinaria uma relação harmoniosa inter-racial, não passava, na verdade, de uma piada cruel.

\section{Relações entre portugueses e africanos}

De acordo com a ideologia racial de Salazar, as populaçôes africanas residentes nos territórios ultramarinos portugueses dividiam-se em duas categorias, os assimilados, ${ }^{4}$ que não constituiriam mais do que cinco por cento da população e vivam nas cidades ou em fazendas de famílias portuguesas, e os restantes, os indígenas (Castelo, 2013). A todos os habitantes dos territórios tutelados, os veteranos se referem genericamente como pretos, pois de certa maneira estavam integrados ou obedeciam à lei colonial vigente. Já a categorização turra, que designa especificamente um membro de um dos movimentos de libertação, seja em Angola (MPLA, ${ }^{5}$ FNLA, ${ }^{6}$ UNITA $^{7}$ ), GuinéBissau (PAIGC ${ }^{8}$ ) ou Moçambique (FRELIMO, ${ }^{9}$ RENAMO $^{10}$ ), tem um carácter intrinsecamente depreciativo. Assim sendo, os soldados portugueses utilizavam esta designação como forma de desvalorizar a luta independentista levada a cabo pelos povos colonizados. Seguindo a lógica do luso-tropicalismo do antigo regime, boa parte

4 Africanos que usufruíram de um estatuto ligeiramente mais vantajoso, em termos laborais, que os restantes.

5 Movimento Popular de Libertação de Angola.

6 Frente Nacional de Libertação de Angola.

7 União Nacional para a Independência Total de Angola.

8 Partido Africano da Independência da Guiné e Cabo Verde.

9 Frente de Libertação de Moçambique.

10 Resistência Nacional Moçambicana. 
das populaçóes africanas, excluindo os membros dos grupos independentistas, estariam aculturadas e imersas nos "superiores valores da naçâo" e a sua coexistência com os portugueses caucasianos seria fraterna e cordial. A retórica do regime náo poderia estar mais afastada da realidade. De acordo com os depoimentos recolhidos, deduz-se que o português comum idealizava o africano vulgar enquanto alguém inelutavelmente inferior. Inferioridade esta que se traduzia numa desconfiança para com boa parte das populaçóes das colónias, mesmo para com as assimiladas ou que viviam nos perímetros urbanos. É natural que numa situação de guerra o receio em relação ao desconhecido e ao divergente seja exponenciado substancialmente, todavia o próprio ideal colonialista, que apresentava Portugal como nação missionária e civilizadora, foi responsável por estereotipar a figura humana africana ainda muito antes do princípio do conflito. Além disso, também as experiências com os superiores militares contribuíam para cimentar o temor. Mário conta que "quando fomos para lá íamos com a ideia de que todo o preto era ladrão ou terrorista, não dava para confiar" (Mário, 2019). Carlos, que vivia na cidade de Tete e se dava sobretudo com assimilados, afirmou que por vezes "o preto era mais racista do que o branco". E deu como exemplo um episódio no qual devido às queimaduras provocadas pelo sol ficou com a pele vermelha, fazendo com os moçambicanos lhe dissessem que "aqui o preto és tu patrâo. A tua pele é que muda, não é a minha". No entanto, acabou depois por dizer que, "apesar de tudo, sempre fui amigo dos pretos, nunca olhei para a cor da pele" (Carlos, 2019). Marco relatou um pequeno episódio com contornos cómicos:

Eu já tinha um receio enorme antes de ir para a Guiné e quando chegámos lá e o barco atracou fiquei logo cheio de medo. Vi tantos pretos fora do barco que me assustei. Até arranquei as divisas do uniforme porque pensei que por ser furriel me iam logo limpar o sebo. Por razões de segurança, até ponderei ir a rastejar do barco até ao quartel para ver se ninguém me topava. Na primeira semana em que lá estive andava sempre desconfiado. Tinha medo de andar no passeio, porque diziam que se andássemos nele os pretos nos davam logo uma catanada. O resto dos meus companheiros pensava o mesmo até que um colega que já lá estava há mais tempo nos disse para ganharmos juízo. No fim de contas, acabei por ter uma vida boa lá porque trabalhava na oficina e nunca tive em perigo. Comi bem e dormi bem. Tive uma vida descansada. (Mário, 2019).

Também no depoimento de José Manuel Gaimito, presente no livro Estranha guerra de uso comum, de Paulo Faria, se encontra um relato de contornos semelhantes:

Uma pessoa chegava a África e tinha medo, é preciso reconhecer, mas também não havia a mínima sensibilidade para nós pôr à vontade [...]. Aquilo era mesmo assim, um gajo saía do navio e vinha cheio de medo, via terroristas em todo o lado. Até quando fizemos escala em Lourenço Marques, íamos na rua, víamos um preto, achávamos logo que era um terrorista. Cada vez que abríamos uma torneira quase tínhamos medo que saísse de lá um jacaré. (Faria, 2016, p. 250-252). 
Mediante as descrições apresentadas, depreende-se que para além dos preconceitos vulgares difundidos pela moral colonial e pelo medo do desconhecido existia ainda uma desconfiança corroborada pelas conceçóes transmitidas pela hierarquia militar e pela própria lógica da propaganda da guerra. De acordo com os fundamentos militares mais elementares, o inimigo é sempre encarado como a fonte de todo o mal, e, portanto, a luta empreendida contra ele é heroica, justa e necessária (Vetter, 2007). Consuma-se entáo uma simbiose entre os princípios militares, que definem o inimigo como a encarnaçáo do mal, e as concepçóes sub-humanizantes do racismo e do colonialismo, que permitem que todo o africano seja um potencial "ladrão ou terrorista" ou "mais racista". Todavia, foram recolhidos testemunhos nos quais alguns veteranos revelaram, já na altura em que foram mobilizados, que tinham uma visão pró-independentista.

Quando inquiridos acerca das suas opinióes em relaçáo à justeza das lutas dos movimentos de libertaçáo, os veteranos expressaram pontos de vista diversos. $\mathrm{O}$ mais comum talvez seja o de revelarem que náo tinham uma opiniáo formada na altura e que se limitavam a cumprir ordens. No entanto, outros afirmaram reconhecer a legitimidade dos movimentos de libertação, mas que ao mesmo tempo consideravam traidores à pátria quem desertava.

Nuno, por exemplo respondeu que "não se pensava no assunto. Até davam umas cervejitas e drogas para náo se pensar muito", dizendo depois: "Limitávamo-nos a ir para o mato e vir do mato, em cumprir a nossa missão. Nós erámos unidos e não nos podíamos dar ao luxo de náo ser" (Nuno, 2019). Também para Mário "a malta não tinha opiniáo formada acerca do assunto. Só pensávamos em cumprir ordens e nada mais" (Mário, 2019).

Já Alves declarou que "enquanto alguns mais politizados poderiam ter uma perspetiva mais complexa das coisas, a maior parte náo tinha capacidade para compreender as verdadeiras razões do conflito" (Alves, 2019). Francisco, por sua vez, fez uma declaração semelhante.

Infere-se, portanto, que, de um modo geral, o grau de despolitização do soldado comum era tal que não seria capaz de formar juízos ou tomar uma posição estruturada quanto às origens do conflito, estando assim particularmente suscetível à absorçáo do ideal colonialista. Por outro lado, Francisco revelou que poderia existir, embora residualmente, um sentimento de desagrado face ao regime colonial e muito provavelmente em relaçáo ao próprio Estado Novo. Francisco foi destacado para Moçambique em janeiro de 1974, justamente nas vésperas do derrube da ditadura, a 25 de abril do mesmo ano. Aliás, Francisco admitiu na entrevista que aquando da sua mobilização o descontentamento face ao regime era tal que "as pessoas já tinham noção que devia ser só uma questão de tempo até o Caetano, ${ }^{11}$ cair" (Francisco, 2019). No entanto, a guerra aguardava-o.

11 Marcello Caetano. Sucessor de António de Oliveira Salazar até ao fim do Estado Novo. 


\section{No Jardim dos Suplícios}

A violência, principal apanágio da guerra, é um fenómeno de tal modo disruptivo que os efeitos provocados no ser humano variam consoante a circunstância e o indivíduo e dificultam interpretaçôes e definiçôes científicas do mesmo. Apesar de inserida no dia-à-dia do soldado que experiencia a campanha bélica, ela certamente náo perde o seu ímpeto, não se banaliza. Pode-se tornar de facto banal para quem a testemunha diariamente, náo inviabilizando, contudo, a influência traumática que a mesma exerce a nível cerebral e comportamental.

Os excessos de toda a índole e os acontecimentos percecionados como inusitados atribuem às experiências decorrentes da guerra algo de etéreo, de insólito, ou até mesmo de inenarrável. Na sua obra, Kapput, sobre a frente de leste da Segunda Guerra Mundial, Curzio Malaparte notou que a guerra tem "qualquer coisa de sonho... ou de pesadelo" (Malaparte, 1984, p. 82). Primo Levi, que esteve num campo de concentração, afirma não saber se aquilo porque passou de facto aconteceu. Para o sobrevivente de uma experiência traumática, a perceção da memória do trauma adquire contornos irreais (Seligmann-Silva, 2008, p. 70). Durante a sua entrevista, Alves asseverou, amiúde, como remate de um relato: "Isto parece mentira para quem está de fora. Eu sei. Até às vezes a mim me custa a acreditar, mas foi mesmo assim" (Alves, 2019). Também Francisco disse: "Quando estive nos soldados pisteiros vi lá coisas que se as contasse me chamavam mentiroso" (Francisco, 2019).

Vivenciar o bizarro, o grotesco e o violento torna-se então prática corrente para o soldado comum que se encontra na frente. Em simultâneo, o modus vivendi da pessoa sofre alteraçôes notáveis, como forma de se adaptar ao meio circundante (König; Reimann, 2018, p. 3).

Alves, que trabalhou na cantina do aquartelamento de Buba, na Guiné, afirmou que quando os fuzileiros se deslocavam até ao quartel e se embriagavam acabavam constantemente por provocar enormes desacatos: "Tinham alcunhas estranhas como Tarzan e Drácula. Quanto entravam na cantina embebedavam-se e andavam à porrada. Eram só garrafas pelo ar, partiam tudo. Mas para a guerra eram do melhor" (Alves, 2019). Contou de seguida, tendo em conta a posiçáo geográfica, ${ }^{12}$ da base em que se encontrava:

Estávamos a sofrer ataques quase todos os dias. Havia mortos quase sempre. Ou por combates, ou por acidentes devido à impreparação do pessoal. Tive um grande azar, grande parte da malta com quem travava amizade acabava por morrer. Tive

12 O aquartelamento de Buba foi um local onde os guerrilheiros do PAIGC concentram bastantes esforços durante 1969 e nos anos procedentes (Afonso; Gomes, 2010, p. 467). 
um colega que rebentou as próprias pernas e matou uma data de camaradas porque pegou numa bazooka que estava ligada à bateria. Já o Ferreira, com quem eu estava a beber uns whiskies, disse-me no bar: 'Amanhá já não estou cá!' e eu respondi: 'Não digas isso!' E foi verdade, no outro dia morreu. Fui eu que levei os restos até Bissau. (Alves, 2019).

Francisco, por sua vez, ao relatar a sua breve experiência numa tropa especial, disse:

Os eventos mais violentos que testemunhei foram durante o meu tempo nos pisteiros de combate ${ }^{13}$. Aquela malta andava drogada e completamente doida. Vi lá coisas que se as contasse me chamavam mentiroso. Eles colecionavam troféus humanos, e fico-me por aqui. Até macacos eles matavam. Diziam que os outros [os membros dos movimentos de libertação] cometiam atrocidades, mas nós não lhes ficamos atrás [...]. (Francisco, 2019).

A exposição constante à violência, quando desenvolve no indivíduo um sentimento de resiliência, pode conduzir a um estado de vício na mesma (König; Reimann, 2018, p. 3-5). Nuno, atirador de cavalaria na zona fronteiriça entre a Guiné-Bissau e a GuinéConakry, conhecida no jargão militar por "corredor da morte", afirmou ter estado envolvido em dezenas de tiroteios e alegou que mesmo após ter sido ferido numa perna continuava a ir em missão:

Apesar de ferido diziam-me para eu não ir para o mato. Mas eu ia sempre! Nunca arranjava desculpas. Como muitos que se faziam de doentes. 'Dói-me isto'. 'Dóime aquilo'. 'Estou doente'. Eu ia sempre. Gostava daquilo. Mas havia lá malta que se assustava com facilidade. Tinha lá um colega que quando fazia sentinela se assustava com tudo. Começava aos tiros por tudo e por nada. Ou tinha visto qualquer coisa no meio da mata ou um preto qualquer tinha-lhe começado a atirar pedras. Passado uns tempos, já nos tínhamos habituado e ninguém ligava [Risos]. (Nuno, 2019).

Tendo em conta os relatos mencionados, infere-se que as vivências de guerra imprimiram marcas permanentes nos entrevistados. Aos vestígios inscritos na psique individual e coletiva provocados por eventos perturbadores, os psiquiatras e sociólogos costumam vulgarmente referir-se como trauma. Já às sequelas provocadas por este tipo de eventos foi atribuída a designação de post-traumatic stress disorder (PSTD).

De um modo sintético, o trauma ocorre através do modo como o corpo e o cérebro reagem particularmente a emoçóes intensas. Ao mesmo tempo, não é o

13 Tropa especial que estava incumbida de seguir os guerrilheiros independentistas e identificar as suas bases. 
evento que define o trauma mas sim o movimento físico e psicológico que o procede. Genericamente, um dos seus atributos é perda do sentido de segurança e de capacidades por parte da pessoa. (König; Reimann, 2018, p. 7).

Se o trauma individual se manifesta através dos traços expostos, o coletivo, poderse-á refletir a partir de três elementos-chave: narrativas, emoções e modelos/valores mentais partilhados pelo grupo que sofreu a ocorrência traumática. As narrativas coletivas tendem a desconsiderar a diferença entre factos e opiniōes e podem apresentarse como seletivas ou distorcidas, ocultando o sentimento de culpa devido às dinâmicas de grupos que conduzem o indivíduo a fazê-lo inconscientemente de forma a preservar a identidade do grupo (König, Reimann 2018, p. 9-13). A memória coletiva procura "definir o que é comum a um grupo e o que, o diferencia dos outros", contribuindo para um reforço dos "sentimentos de pertença e das fronteiras sócio-culturais" (Pollak, 1989, p. 3).

As exposiçóes individuais e coletivas dos veteranos da guerra colonial aos eventos traumáticos por que passaram, levaram-nos à assunção de perspetivas acerca do seu passado que foram refinadas através dos filtros supracitados. Talvez como forma de tentarem atribuir algum sentido, alguma lógica ínfima, ao período da sua vida em que se encontraram imersos num quotidiano pautado pela aleatoriedade, pelo sofrimento e pelo horror.

Como forma de criar ou preservar a identidade pessoal e de grupo, o indivíduo efetua um rememorar do passado através do qual seleciona determinados eventos ou aspetos como historicamente relevantes para o seu percurso vital. $\mathrm{O}$ conceito de sitios de memória, cunhado por Pierre Nora, apesar de remeter para um formato institucionalizado das memórias coletivas, refere que "tanto um arquivo histórico e um monumento, como um apartamento privado guarda aquilo que os seus donos consideram relevante". Neste caso, Nora, assume "sítio" na sua forma literal, material. Onde comunidades, tais como "naçôes, grupos étnicos ou partidos políticos depositam as suas memórias e as consideram partes integrais da sua identidade" (Szpocinski, 2016, p. 245-246).

Assumindo o sítio de memória não na sua aceção materialista, mas enquanto espaço subjectivo e simbólico da psique individual, é possível identificar elementos que no contexto do espaço mental e narrativo surgem como exemplares de uma determinada época da vida de alguém. Se as experiências violentas resultariam, a princípio, nas recordaçóes mais vivas que o veterano levaria consigo dos seus tempos passados em África, também os momentos de confraternização, companheirismo, lazer e fruição marcaram presença nos depoimentos recolhidos. Talvez como forma de encontrar algum equilíbrio emocional ou de tentar retirar algo de positivo da vida em campanha. Ao mesmo tempo, foi também frequente que alguns dos entrevistados recorressem a observaçóes acerca de determinados eventos violentos com laivos de humor negro, à depreciação de acontecimentos extremos e a um desprezo pelas altas instâncias militares, 
acompanhado de uma valorização das suas tarefas e dos seus colegas. Nuno disse: "O Spínola, ${ }^{14}$ e o Carlos Fabiăo, ${ }^{15}$ vinham ao mato para nos ver. Mas aquilo era só para picar o ponto, e era quando as coisas estavam calmas. Depois iam-se embora. Nós é que ficávamos lá a aguentar" (Nuno, 2019). Alves demonstrou uma opiniáo semelhante:

O António de Spínola, que para muitos era um grande homem, para mim não passava de um carrasco. Dava dinheiro à malta para apanharem minas. Chegava a pagar bem até por cada mina encontrada. Mas ele só fazia isso porque não era ele a apanhá-las. Dava belos discursos, tudo á grande e á francesa, mas no fundo só se interessava pelos objetivos militares. Nos é que aguentávamos o barco e ele não conseguia compreender o que sofríamos. (Alves, 2019).

Estes comportamentos, de defesa da integridade de grupo, parecem funcionar enquanto mecanismos de defesa da estabilidade psicológica e emocional dos veteranos.

De igual modo, quase todos os depoimentos recolhidos fizeram referências a bons momentos passados durante o período de destacamento em África. Mário afirmou que "lhe fez bem ir a Moçambique" e Nuno afirmou:

Sofri muito, por causa do ferimento de rocket, ${ }^{16}$ que tenho na perna. Ainda hoje me dói. Nós sofremos muito, é verdade. Mas também foi bom lá estar. Gostei, fez-me bem. A comida era boa, nunca comi tanto como quando lá estive. Os pretos apanhavam gazelas com fartura e depois vendiam-nas porque a religião deles não permitia que as comessem. Era um fartote. E depois a cervejita. Cerveja com fartura. (Nuno, 2019).

Também outros entrevistados fizeram referências à qualidade da gastronomia local, ao consumo de bebidas alcoólicas ou de variantes africanas da cannabis como a ceruma e a liamba. Notando, porém, que eram sempre os seus pares que as fumavam. Quanto a contactos sexuais com mulheres locais, não houve qualquer menção da parte dos entrevistados. No entanto, no livro de memórias da Guerra Colonial, Estranha guerra de uso comum, encontram-se inúmeras referências a essas práticas. O relato de costumes hedonistas pode assim ser encarado como um meio de extrair algo de positivo da experiência de guerra. Como forma de salvaguarda pessoal e coletiva nada será, porém, táo representativo quanto o sentimento de comunidade.

14 Governador militar da Guiné-Bissau.

15 Militar que ocupava o posto de Capitão (oficial de baixa patente) e que haveria de fazer parte do Movimento das Forças Armadas.

16 Ferimentos provocados por fogo de mísseis. 


\section{Sentimento de comunidade}

A experiência do trauma conduz o indivíduo a procurar transpor o acantonamento subjetivo em que se encontra e estabelecer laços, muitas das vezes vitais, com o grupo em que estava inserido aquando da passagem por eventos perturbadores (König; Reimann 2018, p. 12-13). A exposição ao perigo e a incerteza levou à sedimentação de fortes vínculos entre os veteranos, contribuindo consequentemente para o forjar de uma identidade simultaneamente pessoal e geral que é subsistida ao longo da vida dos envolvidos através de processos de ritualização e preservaçáo memorial. Atente-se aos encontros de antigos soldados que se realizam anualmente ou ao website "Dos Veteranos da Guerra do Ultramar", ${ }^{17}$ onde constam as cifras dos mortos em todas as frentes de guerra, fotografias dos encontros anuais e edificação de monumentos, exposição da heráldica militar e noticias acerca dos recentes falecimentos dos veteranos. Estes sítios de memória funcionam enquanto mecanismos de coesão de grupo. Independentemente de alguns antigos soldados terem perspetivado a sua experiência como completamente negativa, não a rejeitam. Antes pelo contrário, consideram-na parte inseparável da sua substância ontológica, como conta José Manuel Gaimito:

Já disse aos meus filhos que quero ser sepultado com a bandeira do Batalhão de Caçadores 1403 por cima do meu caixão. Aquela guerra náo era minha, roubaramme quarenta e quatro meses da minha juventude, mas mesmo assim já tenho a bandeira guardada lá em casa, é esse o meu querer. Aquela guerra não era minha, mas passou a ser minha. (apud Faria, 2016, p. 253).

Marco disse que ainda hoje adora as coisas militares, "como reparo equipamentos mecânicos, às vezes vou ao quartel fazer uns trabalhos e fico sempre fascinado com aquilo, as armas, os carros, as fardas" (Marco, 2019).

Para além do sentimento de união composto em contexto militar, foi verificado que a narrativa coletiva de preservação englobou igualmente a população portuguesa residente nas colónias. Ou seja, os militares e os colonos portugueses percecionavam-se como uma comunidade distinta das próprias populaçóes africanas. Uma vez mais os pressupostos do luso-tropicalismo do Estado Novo são invalidados, na medida em que há uma diferenciaçáo entre nós (caucasianos) e eles (africanos). De acordo com Carlos:

Houve uma coisa que me emocionou muito. Os portugueses que estavam lá recebiam-nos como sendo parte das suas famílias. Para mim ainda nos ajudavam mais do que a nossa própria família. Em parte talvez por sermos da mesma origem e estarmos naquele local, longe daqui. Aquilo levava a uma maior aproximação

17 Disponível em: http://ultramar.terraweb.biz/index.htm. Acedido em 10 de maio de 2021. 
entre as pessoas. Os portugueses lá eram todos uma família. E uma família unida! Até as vezes os pretos que não fossem turras podiam fazer parte da nossa família. (Carlos, 2019).

Mário relatou que "a população branca [colonos] nos desprezava [militares] ao início, antes do começo da guerra", porém, quando o conflito rebentou "a atitude deles mudou completamente e vieram logo pedir-nos batatinhas. A partir de então começaram a tratar-nos como família" (Mário, 2019). A convergência estabelecida entre pessoas que se assumem como da mesma origem, ou que comunguem dos mesmos valores culturais, é uma prática comum nos mais variados contextos. Sendo assim natural que numa situação de perigo esta prática seja enfatizada substancialmente. $\mathrm{O}$ historiador Eric Hobsbawm deu como exemplo o facto de os emigrantes italianos nos Estados Unidos, durante a viragem do século XIX para o século XX, terem recorrido a uma forma protocolar de falar o italiano. Afastados dos seus locais de origem, sicilianos, napolitanos e romanos, abandonaram os seus dialetos locais e substituíramnos por um italiano homogéneo e circunstancial, como forma de salvaguarda e de afirmação identitária (Hobsbawm, 2004, p. 102). De facto, quando uma comunidade necessita de se fundamentar pode recorrer a um rol de diversos elementos, quer eles sejam linguísticos, étnicos, estatais ou territoriais (Anderson, 2017, p. 23-25). No caso dos soldados e residentes portugueses em África, a comunidade alicerçou-se sobre o conceito de nacionalidade. Todavia, de acordo com o depoimento de Carlos, numa nacionalidade que parece ter digerido alguns dos princípios do luso-tropicalismo do Estado Novo.

A exposição a situaçóes de risco e de violência, bem como as prerrogativas inerentes à lógica da instrução militar, contribuem para inscrever traços característicos nos sentimentos de comunidade formados em contexto bélico. O trauma provoca atitudes defensivas ou agressivas que funcionam como elementos de resguardo do grupo, através dos quais se procura preservar a existência, a partilha da mesma realidade, a imagem geral e a coerência de todo o coletivo (König; Reimann, 2018, p. 12-13). Ao mesmo tempo, o enquadramento num cenário de guerra interfere sobre a perceção humana e produz uma alteração cognitiva. Em primeiro lugar, o inimigo passa a representar o mal absoluto, configurando assim uma visão maniqueísta do mundo. Em segundo lugar, a luta contra o adversário torna-se num caminho para alcançar a glória, polvilhado de misticismo e heroísmo, e por fim, aqueles que náo se conformem com as regras do jogo tornam-se automaticamente traidores. Em suma, durante os períodos de guerra é definida uma alteração cognitiva geral que produz uma moral dupla e conduz a que os outros sejam julgados de modo diferente do que nós (Vetter, 2007). É evidente que estes postulados não se podem aplicar de modo categórico a todas as pessoas, no entanto, servem como guia interpretativo dos seguintes depoimentos.

Se Francisco demonstrou desde o princípio reconhecer a legitimidade das lutas dos movimentos independentistas, de modo algo paradoxal, afirmou: "Não 
hostilizávamos as populaçôes. Mas também tínhamos de salvar a nossa pele e defender a pátria". Noutro momento disse: "Diziam que os outros é que cometiam atrocidades, mas nós não lhe ficamos atrás. As maldades deviam ser cometidas $70 \%$ eles, $30 \%$ nós, vá, $60 \%$ eles, $40 \%$ nós" (Francisco, 2019). Ou seja, o inimigo está sujeito a um grau de imputabilidade superior ao nosso. Ao mesmo tempo, "defender a pátria" pode implicar que aqueles que não se submetam às ordens militares, ou, pelos menos, à defesa da integridade do grupo, sejam encarados como traidores. Elpídio Barros afirmou ter "desprezo pelos tipos que desertaram" apesar de "aquela guerra ser uma estupidez". Admitindo mais tarde que, "bem vistas as coisas, talvez fosse melhor ter fugido para a Suíça ou para a Alemanha e passar por cobarde aos olhos de um tipo como eu" (apud Faria, 2016, p. 65-74).

Também a luta pela defesa de uma comunidade ou por uma causa que se arrogue do direito de defender a integridade da mesma comunidade, pode levar a um sentimento de resignação ou até de júbilo perante a morte. $\mathrm{O}$ ato de perecer adquire contornos místicos nessas instâncias. Vítor, técnico de aeronaves em Angola, relatou um pequeno episódio que ilustra esta problemática:

Perguntaste-me há pouco qual era a mentalidade do soldado comum em relaçáo à guerra colonial, não foi? Eu apesar de ter tido sorte e não ter visto guerra presenciei um episódio que me marcou bastante. Uma vez tivemos de ir até ao mato para prestar auxilio técnico a um grupo de para-quedistas que tinha sido emboscado. Um deles, que estava gravemente ferido, foi transportado no helicóptero onde eu vinha. Estava deitado numa maca, tinha buracos de balas no peito e sangrava que nem um porco. Atrás dele estava um companheiro seu que lhe dava chapadas na cara e dizia: 'Foi boa pá. Lutaste bem. E se morreres está descansado que foi em nome da pátria!' Ao que o gajo respondeu orgulhosamente: 'E ainda consegui matar três!' Não sei ele morreu ou não, porque ao chegarmos à base ele foi levado para uma enfermaria qualquer e nunca mais o vi, mas se querias saber qual era a mentalidade dos tropas aqui tens. (Vítor, 2019).

\section{O Humor Negro}

Se o sentido de comunidade representa um dos principais mecanismos de defesa da integridade psicológica do individuo, através do qual se procede a eleição de um sitio de memória reconfortante, que partilha o mesmo espaço territorial e simbólico que o evento traumático, o recurso narrativo e memorial ao humor negro é passível de ser interpretado como um dispositivo análogo. Todavia, ao invés de considerar positivamente uma experiência que surte alento, desvaloriza um evento transtornante 
O conceito de humor negro, popularizado pelo poeta francês André Breton, através da sua obra Antologie de l'humour noir (1940), um compêndio de textos de vários autores que recorrem a uma estética inserida no intervalo entre o macabro e o cómico, não tem definiçóes precisas. Alude, no entanto, para um sentido de humor levado ao extremo. Transcendendo o limite do que pode ser considerado divertido e observando coisas que, quando contempladas de outra maneira, suscitariam o horror, a angústia ou emoções semelhantes. Breton e os seus pares, que no princípio da década de 1920 formaram o movimento surrealista, tiveram uma forte influência das teorias psicanalíticas de Sigmund Freud. O psiquiatra austríaco reivindicava o estudo dos sonhos e do inconsciente como fulcrais para o entendimento da psique humana e considerava o riso como uma ferramenta libertadora, capaz de aliviar o peso da rotina e da dor. Freud desenvolvia a ideia de que o "humor permite que certos conteúdos problemáticos possam ser exteriorizados". O humor (negro) permite assim dizer coisas que num outro contexto não poderiam ser ditas, seja de modo intencional ou inconsciente (Sandoval, 2013, p. 53). Já o filósofo Henri Bergson havia frisado as raízes irracionais e indetermináveis do riso antes de Freud. Assumindo que o mesmo, apesar de poder reportar para a inconclusáo de algo ou para o malogro de um objetivo, tem origens insondáveis (Bergson, 1991).

$\mathrm{O}$ termo humor negro encontra paralelo, ou um género irmão, no chamado humor militar. Num documento partilhado entre veteranos, que foi cedido por Mário, onde se encontram vários episódios de guerra de contornos cómicos, o autor define o humor militar como "aquele que só o é inserido num contexto castrense, ${ }^{18}$ no quotidiano de quartel, em situaçôes de campanha ou mesmo em trágicas situaçóes de guerra. Especialmente aí". ${ }^{19}$ Nesta ordem, o humor surge justamente como um escape que procura atenuar as emoçóes intensas, quer na altura da passagem pelos eventos traumáticos, quer quando estes são rememorados e relatados a terceiros.

Os depoimentos recolhidos permitiram inferir que os que passaram por uma maior quantidade de eventos traumáticos recorriam com maior frequência ao humor negro durante os seus relatos, como plasmaram os depoimentos de Alves e Nuno que estiveram na Guiné-Bissau, a frente de guerra mais violenta. ${ }^{20}$ Tendo em conta a natureza brutal dos mesmos, irá ser apresentado somente um exemplo. Alves descreveu a forma como um colega seu morreu, não num contexto de batalha, mas durante $\mathrm{a}$ pesca:

Esta é outra história que parece mentira. Foi uma morte completamente ridícula.

18 Relativo à classe militar.

19 Este documento privado foi apenas assinado pelo pseudónimo Vaz (grifo meu).

20 Foi na frente de guerra da Guiné-Bissau que se registaram mais baixas, feridos e material militar inutilizado (Afonso; Gomes, 2010). 
Um camarada meu do Minho que adorava peixe costuma pescar com frequência lá em Buba. Ainda por cima aquilo ficava numa zona perto de onde os braços de mar entravam pela Guiné-Bissau adentro. Havia uma quantidade enorme de rios ao pé da nossa base, onde as espécies de peixe abundavam. O meu camarada e alguma malta costumavam pescar com granadas. Atiravam-nas para dentro do rio, aquilo rebentava no fundo, os peixes mortos ficavam a boiar e depois eles apanhavam-nos com uma rede. Um dia ele disse-me: 'Vou apanhar-te ali um sável à maneira'. O peixe nunca veio. Mas ele veio... só que foi aos bocados. O barco virou-se e ele caiu em cima da granada. (Alves, 2019).

A piada surge não como forma de escarnecer o vitimado, mas com o propósito de aligeirar uma situaçáo extrema. Presume-se entáo que o riso dirigido a um sinistrado nem sempre assume contornos cínicos. Por vezes, tendo em conta a sua origem irracional e incontrolável, torna-se num mecanismo de defesa que procura mitigar um evento traumático, como Freud defendeu.

\section{A Guerra: ontem e hoje}

Os efeitos provocados pela experiência de guerra perduram durante toda a vida dos que por ela passam. A exposiçáo a um evento traumático deixa marcas de tal modo inapagáveis que o regresso, consciente ou inconsciente, a esses sítios de memória se torna inevitável.

A este vai e vem constante entre o passado e o presente foi atribuída, pelas autoridades científicas, a definiçáo de post traumatic stress disorder (PSTD), como já havia sido apresentado anteriormente. Esta patologia consiste na forma como a vítima recebe ou interpreta a experiência. $\mathrm{O}$ evento não é assimilado completamente aquando da sua ocorrência, sendo depois revisitado ao longo da vida do traumatizado. De acordo com Cathy Caruth: "Estar traumatizado é ser-se possuído por uma imagem ou um evento" (Caruth, 1995, p. 4-5). ${ }^{21}$

O trauma, dado a sua essência interruptiva, impossibilita a assimilação completa dos eventos perturbantes, deixando a psique num estado de desorientaçáo que dificulta a aceitaçáo de um evento. A capacidade cognitiva é de tal modo afetada que o córtex cerebral, ao náo absorver a experiência por completo, a deixa num estado de suspensão.

Quando inquiridos sobre se a experiência de campanha em África continuava presente, as respostas foram obviamente afirmativas. Mesmo as dos veteranos que não passaram por eventos particularmente traumáticos, como Mário ou Gabriel. Por 
sua vez, Francisco, Alves e Nuno deram respostas mais complexas ou até chocantes. Francisco disse: "Lembro-me sempre dos gajos que morreram e também de um colega meu a borrar-se todo durante um ataque e a chamar pela mãe" (Francisco, 2019). Para Alves: "Sim, um gajo só esquece quando apagamos. É impossível esquecer. Tenho colegas que enlouqueceram. Eu consegui manter o sangue-frio e pôr tudo isso para trás” (Alves, 2019). A resposta de Nuno foi, no entanto, a mais contundente:

Se a experiência de guerra continua presente? Sim. Mais o menos. Ainda o ano passado ia arrancando os olhos à minha mulher. De noite depois de um sonho. Com aquela fúria. Quando a gente se vê no meio do mato. Pensava que ela era um turra. Comecei a sonhar, naquela fúria, naquela coisa. Era capaz de a matar. Ela que o diga! Eu pensava que estava no mato mesmo. (Nuno, 2019).

Os efeitos da PSTD perpetuam-se assim até ao final da vida da pessoa que sofre o trauma. As sequelas latentes da perturbação podem-se manifestar em qualquer circunstância, sujeitando o traumatizado à sua aleatoriedade. Carlos, nos dias seguintes à entrevista, sonhou repetidamente com a sua estadia em Moçambique. Durante a conversa com Nuno, notaram-se comportamentos denotativos da sua relação conturbada com o passado devido ao facto de relatar os combates em que esteve envolvido recorrendo a onomatopeias ou tiques nervosos, como se de facto tivesse regressado ao passado.

Todos os veteranos mostraram uma clara gratidão pelo facto de alguém se mostrar disponível para ouvir as suas histórias. De sentirem as suas experiências e verem os seus relatos valorizados. Confidenciar eventos traumáticos a terceiros pode ser encarado como uma tentativa de "estabelecer uma ponte com os outros" e de iniciar um trabalho de re-conexão com o mundo. "Narrar o trauma, portanto, tem em primeiro lugar este sentido primário de desejo de renascer" (Seligmann-Silva, 2008, p. 66).

Alguns entrevistados revelaram que se sentiam abandonados pelo estado português ou pelas instituiçóes militares. Mário afirmou que muitos veteranos não tiveram recompensas, ou indemnizaçōes após as mutilaçôes sofridas, tal como Alves. O sentimento de abandono por parte dos veteranos pode ser determinado por vários fatores: pela relação traumática com o passado, pela ausência de subsídios e garantias consideradas satisfatórias e pela escassez de debates públicos acerca da guerra colonial. Uma das razóes para a inexistência de discussóes acerca dos efeitos da guerra colonial na sociedade portuguesa será a de que o regime vigente foi instaurado por militares. O Movimento das Forças Armadas, que depôs a ditadura do Estado Novo e instaurou a democracia, foi composto por jovens oficiais de baixa patente que participaram no conflito colonial, como Otelo Saraiva de Carvalho ou o já mencionado Carlos Fabião (Ribeiro; Ribeiro, 2018, p. 282).

No entanto, nos últimos anos tem-se assistido a um retorno a estas questóes. Atente-se aos vários estudos académicos ou à memorialização destas problemáticas 
através do universo das artes, que, progressivamente, têm contribuído para a emersão pública do tema. Será uma necessidade premente que, para além disso, o Estado e as autoridades militares tomem uma responsabilidade mais presente pelos danos físicos e mentais provocados aos veteranos.

Comparando os relatos obtidos através das entrevistas e articulando-os com os presentes no livro Estranha guerra de uso comum podemos encontrar inúmeros paralelos que criam eixos comuns: 1) Uma perceçáo negativa ou conturbada dos colonizados; 2) A criação do sentimento de comunidade tendo em conta a experiencia traumática; 3) A relaçáo paradoxal com o passado que determina a experiência de guerra enquanto algo simultaneamente positivo e negativo; 4) A criação de um sentimento de martirização que desvaloriza grupos exógenos (hierarquias militares, desertores ou africanos).

Refletindo a partir dos eixos enunciados, conclui-se que as consequências da Guerra Colonial Portuguesa perduram até à atualidade e que se manifestam tanto a nível pessoal (trauma) quanto coletivo (perceçấo da alteridade e reuniôes de grupo). Concomitantemente, a ausência de amplos debates acerca do tema, bem como a falta de apoio prestada aos veteranos, indica que a sociedade portuguesa tem procurado evitar confrontar-se com o seu passado e, mais especificamente, com os efeitos que a guerra teve nos soldados que foram forçadamente mobilizados para a mesma.

\section{Referências}

AFONSO, Aniceto; GOMES, Carlos De Matos. Os anos da guerra colonial: 1961-1975. Matosinhos: Quidnovi, 2010.

ANDERSON, Benedict. Comunidades imaginadas: reflexôes sobre a origem e a expansão do nacionalismo. Lisboa: Ediçóes 70, 2017.

BERGSON, Henri. O riso. Lisboa: Relógio de Água, 1991.

BRETON, André. Antologia do humor negro. Lisboa: Ediçōes Afrodite, 1973.

CARUTH, Cathy. Trauma and experience: introdution. In: CARUTH, Cathy (Ed.). Trauma: explorations in memory. Baltimore, Maryland: The John Hopkins University Press, 1995. p. 3-12.

CASTELO, Cláudia. O luso-tropicalismo e o colonialismo português tardio. Buala, Lisboa, 5 mar. 2013. A Ler. Disponível em: http://www.buala.org/pt/a-ler/o-luso-tropicalismo-e-ocolonialismo-portugues-tardio. Acesso em: 10 maio 2021.

CASTELO, Cláudia. O modo português de estar no mundo: o luso-tropicalismo e a ideologia colonial portuguesa (1933-1961). Porto: Ediçôes Afrontamento, 1999.

FARIA, Paulo. Estranha guerra de uso comum. Penafiel: Ítaca, 2016. 
HOBSBAWM, Eric. A questão do nacionalismo: naçóes e nacionalismo desde 1780: programa, mito e realidade. Lisboa: Terramar, 2004.

KÓNIG, Ursula; REIMANN, Cordula. Closing a gap in conflict transformation: understanding collective and transgenerational trauma. 2018. Disponível em:: https:/www.ximpulse.ch/wpcontent/uploads/1806CollectiveTrauma.pdf. Acesso em: 10 mar. 2021.

MALAPARTE, Curzio. Kaputt. Lisboa: Europa-América, 1984.

POLLAK, Michael. Memória, esquecimento, silêncio. Estudos Históricos, Rio de Janeiro, v. 2, n. 3, p. 3-15, 1989. Disponível em: http://www.uel.br/cch/cdph/arqtxt/Memoria_esquecimento_ silencio.pdf. Acesso em: 10 mar. 2021.

RIBEIRO, António Sousa; RIBEIRO, Margarida Calafate. A past that will not go away: the colonial war in portuguese post-memory. Lusotophie, v. 17, n. 2, p. 277-300, 2018.

ROSAS, Fernando. O Estado-Novo (1926-1974). Coordenação de José Mattoso. Lisboa: Círculo de Leitores, 1994. (História de Portugal, 7).

SANDOVAL, Álvoro Luna. Humor negro: una aproximación estética. Dissertação (Licenciatura em Artes) - Universidad de Chile, Santiago de Chile, CL, 2013. Disponível em: http://repositorio. uchile.cl/bitstream/handle/2250/112412/Humor\%20Negro.pdf?sequence=1 \&isAllowed $=y$. Acesso em: 10. mar. 2021.

SELIGMANN-SILVA, Márcio. Narrar o trauma: a questão dos testemunhos de catástrofes históricas. Psicologia Clínica, Rio de Janeiro, v. 20, n. 1, p. 65-82, 2008. Disponível em: http:// www.scielo.br/pdf/pc/v20n1/05.pdf. Acesso em: 10 mar. 2021.

SZPOCINSKI, Andrejz. Sites and non-sites of memory. Teksty Drygue, n. 1, p. 245-254, 2016. Disponível em: https://depot.ceon.pl/bitstream/handle/123456789/14299/14_Szpocinski_ Sites.pdf?sequence=. Acesso em: 10 jun. 2021.

VETTER, Stefan. Understanding human behaviour in times of war. Military Medicine, v. 172, n. 2, p. 7-10, 2007. Disponível: https://academic.oup.com/milmed/article/172/suppl_2/7/4578224. Acesso em: 10 maio 2021.

\section{Fontes Orais}

ALVES (Pseudónimo). [abr. 2019]. Entrevistador: Pedro Miguel Jorge Réquio. PT, 12 abr. 2019. CARLOS (Pseudónimo). [abr. 2019]. Entrevistador: Pedro Miguel Jorge Réquio. PT, 12 abr. 2019.

FRANCISCO (Pseudónimo). [abr. 2019]. Entrevistador: Pedro Miguel Jorge Réquio. PT, 12 abr. 2019.

GABRIEL (Pseudónimo). [abr. 2019]. Entrevistador: Pedro Miguel Jorge Réquio. PT, 12 abr. 2019. 
MARCO (Pseudónimo). [abr. 2019]. Entrevistador: Pedro Miguel Jorge Réquio. PT, 12 abr. 2019.

MÁRIO (Pseudónimo). [abr. 2019]. Entrevistador: Pedro Miguel Jorge Réquio. PT, 12 abr. 2019.

NUNO (Pseudónimo). [abr. 2019]. Entrevistador: Pedro Miguel Jorge Réquio. PT, 19 abr. 2019.

VÍTOR (Pseudónimo). [abr. 2019]. Entrevistador: Pedro Miguel Jorge Réquio. PT, 19 abr. 2019.

Recebido em 11/02/2021.

Versão final reapresentada em 29/04/2021.

Aprovado em 02/05/2021.

Fonte de financiamento: nada a declarar.

Conflitos de interesse: nada a declarar. 